\title{
Industrial Need Analysis in Bakery to Develop Bakepreneurship Learning Model
}

\author{
M. Husin Syarbini*, Budi Santosa, Muhammad Sayuti \\ Master Program of Vocational Education, Universitas Ahmad Dahlan, Yogyakarta, Indonesia \\ *Corresponding author, e-mail: hsyarbini.solo@gmail.com
}

\begin{abstract}
Vocational education has an important role in preparing students to have the skills needed by the industry. This study aims to analyze the needs of the bakery industry to develop a learning model of Bakepreneurship. This study using descriptive qualitative approach by analyzing the needs in the aspect of 1) student, 2) teacher, 3) curriculum, and 4) industry. Based on the analysis results of the stakeholders, we found an idea to develop a Bakepreneurship learning model that can be used as a reference in pastry and bakery learning in the vocational school. Bakepreneurship learning model is a learning model that combines comprehensively aspects of soft skills, hard skills, and entrepreneurship that aim to equip students with the competencies needed by the bakery industry.
\end{abstract}

Keywords: bakepreneurship, entrepreneurship, hard skill, learning model, soft skill.

How to Cite: Syarbini, M.H., Santosa, \& B., Sayuti, M. (2020). Industrial Need Analysis in Bakery to Develop Bakepreneurship Learning Model. Journal of Vocational Education Studies, 3(1), 71-82. DOI: https://doi.org/10.12928/joves.v3i1.1687.

\section{INTRODUCTION}

Vocational education is a form of education unit which has the task to equip students with professional skills to be able to penetrate the job opportunity in the industry based on Law Number 20 the year 2003 on National Education System (MONE, 2003). Vocational education is the education that prepares students to work in particular fields, as well as preparing the graduates to be able to enter the workplace (Nurharjadmo, 2008). Clarke \& Winch (2007) states that vocational education is an effort to develop a social workforce, maintenance, acceleration, and improve the quality of certain workers in the context of increasing community productivity. In the field of vocational education needs to be changed to achievd role and demands of the education law, as well as the needs of the community in equipping vocational graduates with certain competencies, and overcoming unemployment in Indonesia.

Therefore, there needs to reform of vocational education in developing the addition of entrepreneurship learning content with the purpose not just creating the graduates of vocational education are ready to work, but also created the job to work independently as self-employed (Mahfud, 2012). Understanding this increased role will make vocational education has a strategic function to improve employment opportunities by opening new businesses (venture creators). Vocational education should have an effort in bridging the gap competences between education and industry in preparing labor required in the workplace or labor market needs by the industry traditional style of teaching and learning into a more active one in the classroom.

The outlook on the foodservice industry in Indonesia reports that the potential market for foodservice in Indonesia in 2013 was 22.23 trillion, with a predicted growth between (2010 - 2014) of 8.7\% Compound Annual Growth Rate (CAGR). Statistical data submitted by the minister of trade, culinary industry in Indonesia grew 8.16\% in 2015 (Przybylski, 2018). Data on foodservice businesses growth, particularly in the culinary sector has a very fast-growing industry so that the needs of culinary professionals will be very large in number. Vocational education must be actively involved in supporting the 
growth of foodservice businesses by taking the foodservice market share in Indonesia through the creation of new foodpreneur from graduates of the Vocational School

On the other hand, the demand of skilled labor from the industry lack of experience due to the gap between the skill requirements needed and the competencies possessed by graduates. The industry expects certain kinds of competencies, attitudes, cooperation, motivation traits by the SMK graduation which classified as soft skills (Wibowo, 2016). The industry required a high skill labor that is competent, trained and ready to work. People working in the industry must be reliable, responsible, able to solve problems, have social skills and attitude to work together with high performance. According to Sasmito et. al. (2015), the reality shows the opposite, currently, SMK graduates are less ready to work in the industry, because the ability and experience of students are not sufficient and capable to enter the workplace.

In addition to the competence of work required by the industry higher than the competence of SMK graduates. The SMK curriculum is required to create vocational graduates in which compliance of the competencies required by the industry and match with the industry as a middle-level workforce. On the other hand, the SMK graduates is being required to master competencies according to their fields in which they must also be able to develop themselves, as the demands of the changing times.

Vocational Schools are expected to equip their graduates with both cognitive and psychomotor abilities. The reality shows that the existence of SMKs is currently considered to be lacking in preparing graduates as skilled labor. Wardani (2011) argue that there were differences in objectives between the world of education and the industry.

The next domain is to equip vocational graduates with adaptive abilities which is the capability to adapt, adjust and develop themselves according to the newest technology and existing trend in the industries (Kuat, 2018). The adaptive competencies are the basic knowledge and technology material compliance with the capability of respective fields, including the area of competencies related to the foodservice or culinary industry. The development of technology and vocational education that leads to increased competence needed by the culinary industry requires the ability to combine various learning models in which the competencies of students are matched with industry expectations.

The development of the learning process in the Vocational School Expertise Program needs a special consideration when it comes to the competencies expected by the industry which are hard skills, attitudes, cooperation and motivation that is classified in soft skills (Wibowo, 2016). Most schools in Indonesia have not formed graduates to have the above two skills, which in turn graduates will find it difficult to compete in the workforce (Baiti \& Munadi, 2014). The absence of a common vision between school and industry makes the writer want to try to give an idea to minimize the competency gap between SMK graduates and industry demands.

The bakery industry is one of the food industrial fields which is processed any types of food made from various ingredients; combining the wheat flour as the main ingredient with other ingredients such as sugar, margarine, yeast, salt and water through baking process (Syarbini, 2013 ). Based on history, Bakery from the word Pastry and Bakery, which is a kind of shop makes bread in French that specializes in cakes and sweets. In France, the pâtissier is a pastry chef/chef who has graduated from long training, both in practice and in writing. The term Pastry And Bakery also refers to processed pastry products produced by a pâtissier. Thus, the word patisseries come from French, "pậtisserie" which means cakes. Bakery in the hospitality industry refer to one part of pastry station in which responsible to make various pieces of bread for pastry corner, breakfast, coffee break, lunch and dinner (Sheany, 2014).

The bakery has various definitions and term, the field of the bakery industry will require skillfull professionals in making products as well as soft skills, attitudes, and entrepreneurship skills. The reality shows, learning pastry and bakery in educational field 
is still lacking in compliance of the competencies required for the job, mainly using demonstration methods and practices with job sheet media (Sunarmi, 2015). This condition is not enough for preparing students to enter the workplace. Therefore, it is necessary to develop a more comprehensive learning model to prepare students have varous skills match with the industry. The learning model in vocational education that was developed, has purposes for bridging the gap between an education world and the industry, particularly between the bakery industry and the culinary expertise program. One of the criteria that must be possessed by vocational education, is the orientation of individual performance in the world of work should be possessed with real needs in the field with a diverse range of abilities and interests (Sasmito et. al., 2015).

A learning model is a systematic approach used in the learning process. Vocational education, in particular, the Vocational School Food Skills Program must use a learning process with a learning model that can produce the competencies of students of culinary graduates that lead to the competencies needed by the bakery industry. Various learning models have been developed by experts in their fields. Each learning model has a certain character with different uses under the objectives and teaching areas that are developed.

According to Joyce et. al. (2000), the learning model is a plan that is used as a reference in classroom or tutorial learning in learning and tools for determining to learn and directs the teacher in designing ways of learning to help students achieve learning goals. Learning model is a basic stage that includes, analysis, development, manufacturing of teaching materials and evaluation of learning objectives that function to facilitate students in achieving learning objectives. Gunter et. al. (1990) define a learning model as a step-by-step procedure that leads to specific learning outcomes.

Joyce \& Weil (1980) define the learning model as a conceptual framework that is used to guide the implementation of learning. To develop the learning model required need analysis from particular stakeholders such as; (1) students, (2) teachers, (3) curriculum and (4) industry (Hamidah, 2012). This article aims to uncover the analysis of the learning model needs from various aspects of students, teachers, curriculum and the industry, especially the bakery industry.

\section{RESEARCH METHOD}

This research conducted in SMK Negeri 7 Surakarta, adressed at Ahmad Yani Road Surakarta. This study is descriptive qualitative, with the participants of this research are students and teachers majoring in Catering at SMK 7 Surakarta. Data collection technique involve both interview and questionnaire. The data collected from students using a questionnaire technique, while for the teachers done by using interviews. The selection of SMKN 7 Surakarta as a place for taking data is based on the completeness and reliability of the school in the field of Catering, as well as variations in the competency of teachers who has experiences from the catering industry. For the subject of the questionnaire used students of SMK 7 culinary class XII who have followed the practice of fieldwork, so they already have experience in contact with the Industry.

The instruments used in this study are the guideline for making questionnaire to determine students' attitudes, opinions, and perceptions of the needs of the Pastry and Bakery learning model at SMKN 7 Surakarta, using a Likert scale, with the measured variables broken down into indicator variables. Then the indicators are used as instruments in the form of questions that need to be answered by respondents. The guideline aspects measured include: (1) the need for integration both theory and practical in learning, (2) the conformity of theory with the SOP of bread-making process in industry, (3) the suitability of teaching standard operational procedures (SOP) with industrial bread making, (4) The teaching needs of production planning through the calculation of raw 
material requirements needed, (5) Teaching needs to calculate the cost of production according to industry, (6) improvement of entrepreneurial skills through understanding product pricing determination, (7) The suitability of practical session with SOPs in the industry, (8) suitability of teaching selling price calculation with industry-standard SOPs, (9) teaching the bakery business model, (10) teaching material for the calculation of business profit and loss.

\section{Data collection through interviews}

While the other data collected through interviewing teachers in the field of Catering, especially those who are in charge of pastry and bakery subjects, to explore the need for learning models that are following the competency requirements needed by industry.

\section{Research data analysis techniques}

The data analysis technique used in this study is methodological triangulation, which is a way for researchers to test the validity of data by collecting similar data but by using different data collection techniques or methods. The data to be revealed is the student's response to the needs analysis of the pastry and bakery learning model, by continuing on the three steps of data analysis namely data reduction, data presentation and concluding. Explanations related to the three steps of data analysis are as follows:

\section{Data reduction}

Data reduction was carried out after all students' response data to the analysis of the needs of the pastry and bakery learning models and their validity was tested. The process of reducing data in this study is to select student response data. Selection is done by reducing the response data of students who have different response tendencies than the general student response tendency. Through the data selection process, it is expected that research data will become simpler to facilitate the process of concluding.

\section{Presentation of data}

Presentation of data in this study is by narrating student response data that has been reduced with a systematic, structured narrative so that it is easily understood by the reader. The process of presenting this data aims so that what the researcher wants to convey can be well received by the reader.

\section{Conclusion}

The conclusion drawn in this study is to answer the problems raised in this study so that through this conclusion we can find out how students' responses in general to the analysis of the needs of the pastry and bakery learning model.

\section{RESULTS AND DISCUSSION}

\section{The analysis of needs of students}

The study conducted with descriptive approach to uncover the needs of students by using a Likert scale by determining the answer score are: SS (strongly agree) $=5$; $\mathrm{S}$ (agree) $=4$; (moderate agree) $=3$; $($ not agree $)=2$; and (strongly disagree) $=1$ (Widoyoko, 2018). Based on the findings in the field regarding the needs of the learning model given to the subject as many as 30 students of class 7 of SMKN 7, who have participated in internship (PKL) program. The following was the outcome from the student's feedback to support students' needs to have Pastry and Bakery competencies match with the competencies required by industry. From the measurement results of all respondents, it is described in the descriptive statistics on the actual data has score range between $131-141$. The score range calculation is presented in Table 1. 
Table 1. The Point Scale of student's feedback to support students' needs to have Pastry and Bakery competencies match with the competencies required by industry

\begin{tabular}{cc}
\hline Number of answer scores & Score classification \\
\hline $121-150$ & Strongly agree \\
$91-120$ & Agree \\
$61-90$ & Moderate agree \\
$31-60$ & Not Agree \\
$0-30$ & Strongly disagree \\
\hline
\end{tabular}

While the results of the calculation of the ideal score (criteria) for each item are calculated based on the following formula:

Critical Score $=$ Scale value $\mathrm{x}$ Number of respondents

$\mathrm{T}=$ Total number of respondents who voted

Pn $\quad=$ Choice of Likert score

$\mathrm{Y} \quad=$ Highest score $=5 \times 30=150$

$\mathrm{X} \quad=$ Lowest score $=1 \times 30=30$

The results of the score calculation for each statement is presented in Table 2 .

Table 2. The score calculation for each statement

\begin{tabular}{ll}
\hline Formula & Scale \\
\hline $5 \times 30=150$ & Strongly agree \\
$4 \times 30=120$ & Agree \\
$3 \times 30=90$ & Moderat agree \\
$2 \times 30=60$ & Not agree \\
$1 \times 30=30$ & Strongly disagree \\
\hline
\end{tabular}

From the calculation results above, a rating scale is obtained;

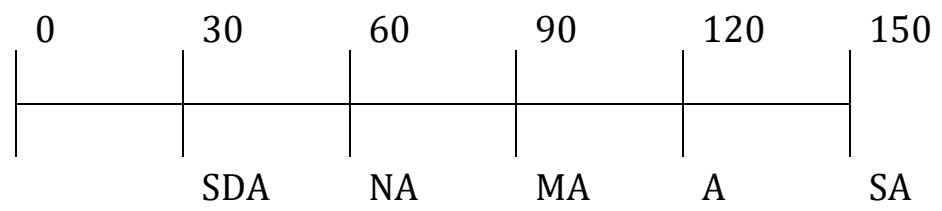

The results of the questionnaire from the aspect of students obtained the following Table 3. 
Table 3. The results of the questionnaire from the aspect of students

\begin{tabular}{|c|c|c|c|}
\hline No & Statement & Score & Criteria \\
\hline 1 & $\begin{array}{l}\text { The need for integration both theory and } \\
\text { practical in learning }\end{array}$ & 141 & $\begin{array}{l}\text { Strongly } \\
\text { Agree }\end{array}$ \\
\hline 2 & $\begin{array}{l}\text { The conformity of theory with the SOP of } \\
\text { bread-making process in industry }\end{array}$ & 128 & $\begin{array}{l}\text { Strongly } \\
\text { Agree }\end{array}$ \\
\hline 3 & $\begin{array}{l}\text { The suitability of teaching standard } \\
\text { operational procedures (SOP) with } \\
\text { industrial bread making }\end{array}$ & 133 & $\begin{array}{l}\text { Strongly } \\
\text { Agree }\end{array}$ \\
\hline 4 & $\begin{array}{l}\text { The teaching needs of production planning } \\
\text { through the calculation of raw material } \\
\text { requirements needed }\end{array}$ & 133 & $\begin{array}{l}\text { Strongly } \\
\text { Agree }\end{array}$ \\
\hline 5 & $\begin{array}{l}\text { Teaching needs to calculate the cost of } \\
\text { production according to industry }\end{array}$ & 134 & $\begin{array}{l}\text { Strongly } \\
\text { Agree }\end{array}$ \\
\hline 6 & $\begin{array}{l}\text { Improvement of entrepreneurial skills } \\
\text { through understanding product pricing } \\
\text { determination }\end{array}$ & 133 & $\begin{array}{l}\text { Strongly } \\
\text { Agree }\end{array}$ \\
\hline 7 & $\begin{array}{l}\text { The suitability of practical session with } \\
\text { SOPs in the industry }\end{array}$ & 131 & $\begin{array}{l}\text { Strongly } \\
\text { Agree }\end{array}$ \\
\hline 8 & $\begin{array}{l}\text { The suitability of teaching selling price } \\
\text { calculation with industry-standard SOPs }\end{array}$ & 128 & $\begin{array}{l}\text { Strongly } \\
\text { Agree }\end{array}$ \\
\hline 9 & Teaching the bakery business model & 132 & $\begin{array}{l}\text { Strongly } \\
\text { Agree }\end{array}$ \\
\hline 10 & $\begin{array}{l}\text { Teaching material for the calculation of } \\
\text { business profit and loss. }\end{array}$ & 141 & $\begin{array}{l}\text { Strongly } \\
\text { Agree }\end{array}$ \\
\hline
\end{tabular}

The teaching needs of Pastry and Bakery for students strongly agree to be taught throughout the learning process so that they have technical competence, soft skills in terms of the process following the SOP needed by industry and entrepreneurship skills.

\section{The need of analysis of teachers}

Based on the results of the interview delivered the analysis of teacher or teacher needs can be obtained a description that Subject 1 states; aspects of the competencies required by students to have the competencies needed by industry must have the same SOP understanding as existing SOPs in the industry, and it states that "the teacher must emphasize how the students works in accordance with the SOP steps", so students have the mindset like industry". While the opinion of Subject 2 states that students have competencies such as competencies needed by industry, "students must have entrepreneurial skills because of when the person make a product, the-end purposes is for selling". According to subject 2, the competency requirements that must be taught in the SMK Catering Program are more focused on entrepreneurship skills. Based on the opinions of Subject 1 and Subject 2, it can be referred that the competencies that must be possessed by students of Food Catering are competencies related to Standard Operating Procedure (SOP) both in theory or practice, as well as entrepreneurship skills. Based on teachers interviewed concluded that the competencies should be taught include competencies related to the understanding of Standard Operating Procedures (SOP) both 
in theory and practice that must be following existing SOPs in the industry and an understanding of entrepreneurship from aspects of theory and practice.

\section{The need of analysis of the SMK Curriculum}

The development of learning models in vocational education is based on developing entrepreneurship competencies that can express entrepreneurial behavior. According to Puskur (2010) the entrepreneurship education framework must be integrated in the learning process through; (1) implementation of character education in all subjects of entrepreneurship, (2) learning entrepreneurship classes, (3) extra-curricular entrepreneurial activities, (4) entrepreneurial activities through self-development and (5) development of school culture as a medium for internalizing entrepreneurial character to the school community. Entrepreneurship is not only managerial and business skills. It also included the aspects of mental attitude and behavior that reflect the characteristics of an entrepreneur. According to Welsa (2018), the character as an entrepreneur is described as someone who can see and assess business opportunities; gather the resources needed to take advantage of it and take appropriate action, to ensure success. Among academics and researchers, the word entrepreneur has many meanings as conveyed by the World Economic Forum (Nugroho, 2016). The word of entrepreneurship has meanings illustrated in Figure 1.

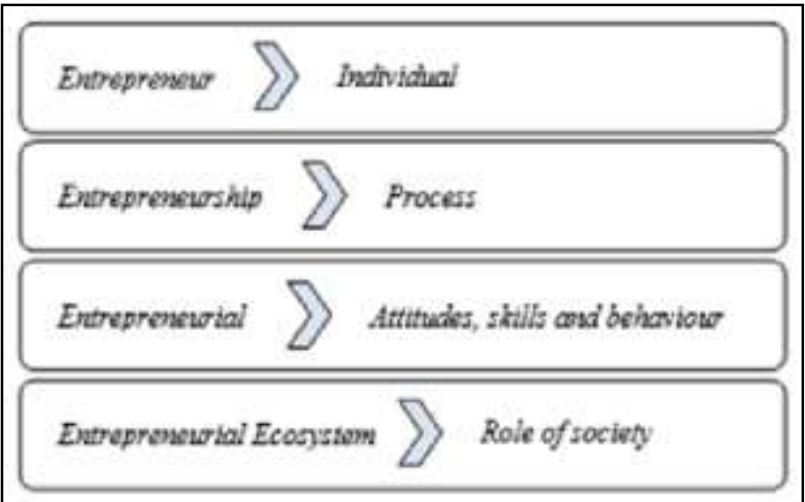

Figure 1. Entrepreneur definitions

The broad scope of definition has influences many learning models which are delivered by experts in creating entrepreneurial learning models, as stated by Lackeus (2015) in Figure 2. 


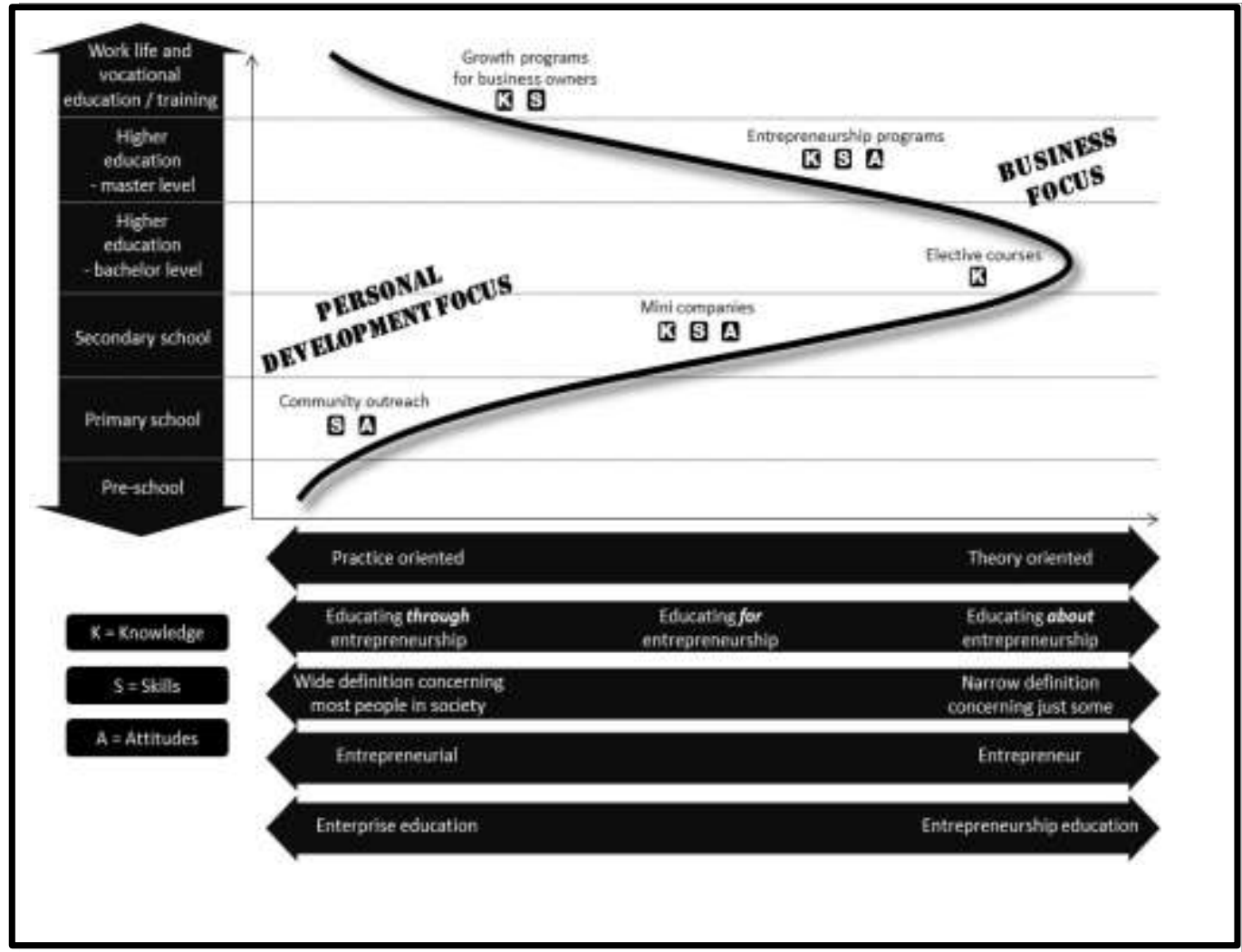

Figure 2: The term used in explaining the notion of entrepreneurship education

The curriculum is a set of plans and arrangements regarding the objectives, content, and learning materials as well as the methods used to guide the implementation of learning activities to achieve certain educational goals. Reviewing aspects of the current Curriculum using the Education Unit Level Curriculum (KTSP) and the 2013 Curriculum, some of the Catering SMK Skills Programs have used the 2013 Curriculum and others using KTSP.

Based on curriculum used,the teachers are expected to be able to apply learning models that are in accordance with market demand and develop a creative economy in Indonesia with the target of the educational ecosystem, which includes: (1) Students; (2) Teacher; (3) Educational Personnel; (4) Parents/guardians; (5) School committee; (6) Alumni; (7) Society / Industrial world; (8) Department of Education; (9) Tourism Office or related service. Based on the phenomenon of learning that occurs, it is necessary to design an SMK learning model of culinary expertise program starting from the planning stage, the process stage, to the learning assessment stage that is in line with the needs of the business world of the catering industry (MONE, 2016).

The curriculum designed considering all aspect that vocational education must teach the competencies needed by the culinary industry, in the form of learning that combines various learning models, so that student competencies are in line with industry expectations, taking into account the competencies expected by the industry, namely skills according to their fields (hard skills) and competencies attitude, cooperation, motivation which is classified as soft skills.

\section{Analysis of the needs of industry}

An overview of the aspects of the industry's need for vocational graduates' competencies is competence which consists of skills under their fields (hard skills) and competency attitudes, cooperation, the motivation that is classified as soft skills. According to Wibowo 
(2016) competency requirements are expected by the industry, namely skills under their fields (hard skills) and competence in attitudes, cooperation, the motivation that is classified in soft skills. Hard skills competency is a skill used to work according to the field of expertise, while soft skills competency is used to support workers completing their tasks. The basic skills are learned when graduates are at SMK through the learning process while soft skills besides at school can also be taught with habituation in the school or outside the school environment. Chaturdevi et. al. (2011) suggested that mastery of graduate skills related to work is not enough, because mastery of soft skills is important especially for business. Based on the findings of the needs of various aspects of (1) students, (2) teachers, (3) curriculum and (4) industrial world, the idea emerged to develop a Bakepreneurship Learning Model that combines aspects of hard skills in the technical process of making bread in accordance with standard operating procedures in the bakery field soft skills and entrepreneurial skills. On the other hand, the industry requires workers with skills per their fields and competencies in attitudes, cooperation and highly motivated who are classified in soft skills.

\section{CONCLUSIONS}

Based on the need analysis of the Bakepreneurship learning model, from various stakeholders we can see that the student analysis results show that; students need a learning model that teaches them to have technical competencies, soft skills in terms of the production process following the SOP needed by industry and entrepreneurship skills. The results of teacher analysis, on the other hand, can be more specific in teaching competence related to Standard Operating Procedures (SOP) both in theory and practice compliance with existing SOPs in the industry as well as the entrepreneurship. The results of the curriculum analysis conclude that Vocational education should provide the competencies needed in the culinary industry by combining various learning models in which the competencies of students are in line with industry expectations as well as the competencies expected by the industry such as; hard skill, attitude competencies, cooperation, motivation which is classified as soft skills. The analysis of the industry needs shows that; The industry is looking for the people who have skills comply with their fields as classified as soft skill such as good attitudes and cooperation.

The overall needs analysis above is the basis of development for Bakepreneurship learning model which is a reference as learning model that will be developed to match with the competencies needed by SMK students in the area of soft skills, hard skills, and entrepreneurship

\section{ACKNOWLEDGEMENT}

We thank the Master Program of Vocational Teacher Education at Universitas Ahmad Dahlan University for providing guidance and support for the article writing.

\section{REFERENCES}

Baiti, A. A. \& Munadi, S. (2014). Pengaruh pengalaman praktik, prestasi belajar dasar kejuruan dan dukungan orang tua terhadap kesiapan kerja siswa SMK. Jurnal Pendidikan Vokasi, 4(2).

Chaturvedi, A. Yadav, A. \& Bajpai, S. (2011). Communicative approach to soft and hard skills. Journal VSRD-International of bussiness \& management research, 1(1).

Clarke, L., \& Winch, C. (2007). Vocational education international approach, development and system. New York: Routledge. 
Günter, M. A., Estes, T. H., \& Schwab, J. H. (1990). Instruction: A models approach. Allyn \& Bacon.

Hamidah, S. (2012). Model pembelajaran soft skill terintegrasi pada siswa SMK program studi keahlian tata boga. Jurnal Pendidikan Vokasi, 2(1).

Joyce, B., \& Weil, M. (1980). Model of Teaching. Second Edition. Engelwood New Jersey: Prentice-Hall, Inc.

Joyce, B., Weil, M., \& Calhoun, E. (2000). Model of teaching. Boston-London: Allyn and Bacon.

Kuat, T. (2018). Implementation of Edupreneurship through the teaching factory in vocational high school of hotel accommodation: Case study at SMK N 6 Yogyakarta. Journal of Vocational Education Studies, 1(1), 7-12.

Lackeus, M. (2015). Entrepreneurship in education what, why, when, how. Entrepreneurship 360 background paper. Paris: OECD.

Mahfud, T. (2012). Praksis pembelajaran kewirausahaan pada unit produksi jasa boga. Jurnal Pendidikan Vokasi, 2(1).

MONE. (2003). Undang-Undang Nomor 20 Tahun 2003 tentang Sistem Pendidikan Nasional. Jakarta: Ministry of Education and Culture.

Nurharjadmo, W. (2008). Evaluasi implementasi kebijakan pendidikan sistem ganda di sekolah kejuruan. Spirit Publik, 4(2), 215-228.

Nugroho, R. L. (2016). Pendidikan Entrepreneurship di Perguruan Tinggi: Studi Tentang Filosofi, Kebijakan, Strategi dan Program Pendidikan Entrepreneurship untuk Menciptakan Generasi Entrepreneur Masa Depan di Institut Teknologi Bandung, Universitas Pendidikan Indonesia, Universitas Kristen Maranatha, dan Institut Manajemen Telkom di Bandung. Telkom University. Retrieved from: www.researchgate.net/publication/306356624_Dissertation_PENDIDIKAN_ENTRE PRENEURSHIP_DI_PERGURUAN_TINGGI_3.

MONE. (2008). Kurikulum tingkat satuan pendidikan (KTSP). Jakarta: Direktorat Jenderal Peningkatan Mutu Pendidik dan Tenaga Kependidikan, Departemen Pendidikan Nasional.

Przybylski, N. (2018). Outlook on the Food Service Industry in Indonesia: Indonesa Investment. Retrieved from: https://www.indonesiainvestments.com/business/business-columns/outlook-on-the-food-serviceindustri-in-indonesia/item 9001.

Puskur. (2010). Pengembangan Pendidikan Kewirausahaan: Bahan Pelatihan Penguatan Metodologi Pembelajaran Berdasarkan Nilai-Nilai Budaya untuk Membentuk Daya Saing dan Karakter Bangsa. Jakarta: Pusat Kurikulum Balitbang Kemendiknas.

Sasmito, A. P. Kustono, D. \& Patmanthara, S. (2015). Kesiapan memasuki Dunia Usaha/Dunia Industri (DU/DI) siswa paket keahlian rekayasa perangkat lunak di SMK Teknologi dan Kejuruan. Jurnal teknologi Kejuruan dan Pengajaran, 38(1).

Sunarmi, T. (2015). Pengembangan multimedia pembelajaran patiseri untuk siswa tingkat XI SMK. Jurnal Pendidikan Vokasi, 5, 134.

Syarbini, M. H. (2013). A-Z bakery: fungsi bahan, proses pembuatan, panduan menjadi bakepreneur. Surakata: PT. Tiga Serangkai Pustaka Mandiri.

Sheany, S. (2014). Hubungan antara program pastry dan bakery dengan sikap kewirausahaan peserta didik di Lembaga Kursus Surabaya Hotel School (SHS) Kota Surabaya. J+ PLUS UNESA, 3(1). 
Welsa, H. (2018). Pengaruh Kewirausahaan terhadap Kemampuan Usaha serta Kinerja Usaha Rumah Makan Padang di Daerah Istimewa Yogyakarta. EKUITAS (Jurnal Ekonomi dan Keuangan), 13(3), 371-387.

Widoyoko, S. E. (2018). Teknik Penyusunan Instrumen Penelitian. Yogyakarta: Pustaka Pelajar.

Wardani, D. (2011). Kontribusi keterampilan social dalam pembelajaran IPS terhadap kesiapan kerja praktik kerja industri. Jurnal Edisi Khusus, 2.

Wibowo, N. (2016). Upaya memperkecil kesenjangan kompetensi lulusan sekolah menengah kejuruan dengan tuntutan dunia industry. Jurnal Pendidikan Teknologi dan Kejuruan, 23(1), 45 - 59. 
